\title{
Effects of Adding Some Natural Substances to Biodiesel to Control its Effect on Carbon Steel Corrosion
}

\author{
Paulo Moura Bispo de Santana ${ }^{a}$, Marilena Meira ${ }^{a}$, Eduardo Kirinus Tentardini ${ }^{b}$ \\ anstituto Federal de Educação, Ciência e Tecnologia da Bahia - IFBA, Campus Simões Filho, \\ Via Universitária, s/n, Pitanguinhas, CEP 43700-000, Simões Filho, BA, Brazil \\ ${ }^{b}$ Departamento de Ciência e Engenharia de Materiais, Universidade Federal de Sergipe - UFS, \\ Av. Marechal Rondon, s/n, CEP 49100-000, São Cristóvão, SE, Brazil
}

Received: November 14, 2014; Revised: August 4, 2015

\begin{abstract}
Biodiesel consists of long-chain fatty acid esters and it presents relatively inert behavior right after its production. However, structural changes occur during its storage, as this fuel has low oxidative stability, fact that increases its corrosivity. The problem of corrosion has become increasingly relevant due to the Government's policy of setting a gradual increase in the percentage of biodiesel added to diesel. The current study evaluated the effectiveness of three natural products to work as corrosion inhibitor in biodiesel. The evaluation was done by means of immersion tests and electrochemical impedance spectroscopy. Results showed that it is possible to reduce biodiesel influence on carbon steel corrosion and that it can be extend to other metals used in automotive engines.
\end{abstract}

Keywords: corrosion, biodiesel, corrosion inhibitor

\section{Introduction}

The sources of sustainable and renewable energy became more attractive due to their environmental benefits. In this context, the production and use of biodiesel allow the development of an important sustainable energy source in terms of environmental, economic and social aspects.

Unlike fossil fuels, which are relatively inert and therefore keep their physical and chemical stability little changed, biodiesel degrades over the time due to oxidation reactions, humidity absorption and microorganism attacks ${ }^{1}$. Many products such as peroxides and hydroperoxides are formed as consequence of degradation and they are converted into aldehydes, ketones and acids. These last three products lead to the formation of free radicals due to their chemical features. They work synergistically and modify fuels' properties by increasing their degradation and, consequently, corrosivity ${ }^{2}$. The continuous increase in corrosivity is mainly caused by the formation of many acids: formic, acetic, propionic and caproic acids, among other ${ }^{3}$.

Another relevant subject consists of the fact that biodiesel is thirty times more hygroscopic than mineral diesel and it means that biodiesel has greater natural tendency to absorb humidity. As a consequence, the water in biodiesel may condense over the metal surface or accelerate the hydrolysis reactions, affecting its quality ${ }^{2,4}$. Besides the presence of water, the water temperature, the contact with air and the light incidence favor the increase of biodiesel corrosivity ${ }^{1,4-7}$. When biodiesel causes corrosion of a metal surface, the liberation of metal ions occurs as consequence of it. This liberation works as a catalyst of chemical reactions in the formation of free radicals. Thus, biodiesel degradation speeds up ${ }^{4,6,7}$.

*e-mail: poumou@hotmail.com
Due to biodiesel low hydrolytic and oxidative stability, its storage is a critical factor because it may change the quality of the product and promote a corrosion that would be practically null with the use of petroleum diesel $1^{1-3,5}$. Such negative results lead to vulnerability and generate problems that may compromise the use of biodiesel as a viable alternative for the existing fuel matrix found in the market.

Corrosion inhibitors are added to the medium in order to prevent metallic corrosion during the gaseous, aqueous or oil phase. The protection given by the inhibitors depends on the type of metal or metal alloy, as well as on the corrosive medium itself ${ }^{8}$. Inhibitors may not totally prevent corrosion, but they may extend the time before corrosion starts to affect the metal exposed to the corrosive medium ${ }^{9}$.

Carboxylic acids, amines, and amine salts of carboxylic acids such as alkyl- or polyalkyl-succinics and their esters, dimeric acids, and amine-salt may be used as corrosion inhibitors in diesel ${ }^{10}$. Amine based compounds, including primary amines, diamines, aminoamines and oxyalkylated amines are the most effective inhibitors. However, the type of corrosion inhibitors will be different for these two fuels, since the composition of biodiesel (fatty acidmono-alkyl esters) is different from that of mineral diesel (hydrocarbons) ${ }^{9}$.

Hancsók et al. ${ }^{11}$, developed multifunctional additives based on rapeseed oil methyl ester. They applied the radical initiation to the widely used thermal synthesis method in an economic way, in order to cause less environmental impact during the production of polyisobutylene (PIB)-succinimide type additives. These synthesized additives showed corrosion inhibition and lubricity in diesel fuel, $5 \%$ biodiesel containing diesel fuel and 100\% biodiesel using 20 ppm SID [succinimid derivative (SID) from polyisobutylene (PIB). 
Almeida et al. ${ }^{12}$, studied the behavior of the antioxidant tert-butylhydroquinone in diesel's storage stability and corrosive character. Diesel oxidation stability was considerably affected after 24 hours in static immersion test using copper coupons. A similar result was obtained for the TBHQ-doped biodiesel after 24 hours in immersion. It indicated that the antioxidant did not retard biodiesel degradation under the same conditions. On the other hand, copper release was less intense in TBHQ-doped biodiesel, fact that provided evidences that the antioxidant retarded the corrosion process because it worked as corrosion inhibitor due to the formation of a protective film layer.

Jakeria et al. ${ }^{13}$ investigated the effect of the organic corrosion inhibitors benzotriazole and adenine in palm biodiesel carbon steel and copper. They concluded that benzotriazole was the most effective in both studied metals.

Dingfeng et al. ${ }^{14}$ compared palm biodiesel corrosivity with commercial diesel in an immersion test, using carbon steel (1045) in three temperatures. The authors concluded that biodiesel is more corrosive.

Yoo et al. ${ }^{15}$ investigated the corrosion inhibition behavior of biodiesel-based 2-(2-alkyl-4,5-dihydro-1H-imidazol-1-yl) ethanol derivatives (A-DIEs). They concluded that the presence of double bonds and functional groups in the A-DIE chains and their sufficiently long chain length enhanced the attachment of A-DIEs on the metal surface, thus leading to high efficiency in corrosion inhibition.

Carbon steel is the mostly used material in the manufacturing of equipment and pipes for biodiesel handling. Therefore, the current study assessed the effects of following substances addition to biodiesel: stearic acid, beta-carotene and propyl gallate, in order to reduce carbon steel corrosion. The stearic acid was selected because it presents a polar chemical structure that could promote film layer formation on the metal surface. Beta-carotene and propyl gallate were selected because they are antioxidant substances.

\section{Experimental}

\subsection{Additives and reagents}

Octadecanoic acid (stearic acid, S4751), $\beta$-Carotene (Beta-Carotene, 1065480) 3,4,5-Trihydroxybenzoic acid propyl ester (Propyl Gallate, S48710) were used in the experiment. Figure 1 shows the chemical structures of the additives. Reagents and additives were purchased from Sigma-Aldrich according to the standard analytical grade. A soy-based biodiesel (B100, Oleoplan Nordeste Oil Company, Brazil) was used in the experiment.

\subsection{Electrode and coupons production}

The electrode (32 $\mathrm{mm}$ diameter and $5 \mathrm{~mm}$ thickness) and the coupons $(12.37 \mathrm{~mm} \times 75.65 \mathrm{~mm} \times 1.50 \mathrm{~mm}$ and $4.75 \mathrm{~mm}$ diameter hole) used in the tests were made of carbon steel SAE-1018.

\subsection{The biodiesel samples}

Four different samples were prepared: pure biodiesel (BD), biodiesel with stearic acid (BD+EA), biodiesel with

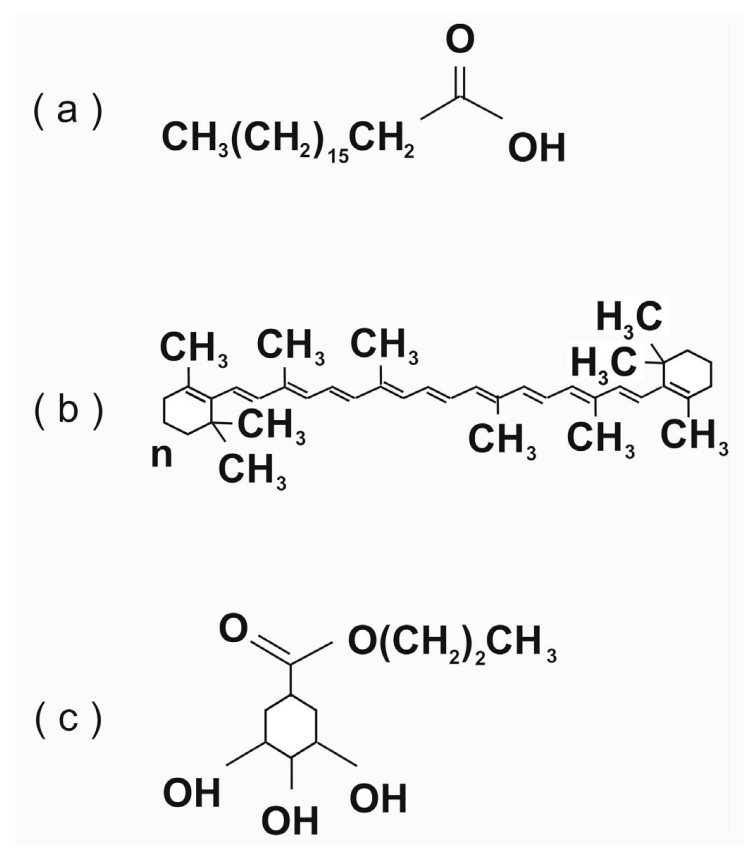

Figure 1. Chemical structure of the additives. (a) Stearic acid (b) Beta-carotene (c) propyl gallate.

propyl gallate $(\mathrm{BD}+\mathrm{GP})$ and biodiesel with Beta-carotene (BD+BC). Used a concentration of $400 \mathrm{ppm}$ for all Additives.

\subsection{Experiment set up and electrochemical measurements}

Immersion test: a metallic carbon steel sample was exposed to four different electrolytes: (BD), (BD+EA), (BD+GP) ( $\mathrm{BD}+\mathrm{BC})$. The tests were conducted at $50{ }^{\circ} \mathrm{C}$ and after four months, the corrosion rate of the metal was determined through mass loss measurements. All measurements were made in triplicate.

Test NACE TM-0172: this test consisted of checking the visual changes in standard carbon steel bodies-of-evidence unrested immersed for four hours in (BD), (BD+EA), (BD+GP) $(\mathrm{BD}+\mathrm{BC})$. Ten percent $(10 \%)$ of water was added to each of these systems ( $\mathrm{pH} 7.0)$. The test was carried out at $50{ }^{\circ} \mathrm{C}$.

EIS Test: Electrochemical measurements were performed in four different corrosion cell types: $\mathrm{BD}, \mathrm{BD}+\mathrm{EA}, \mathrm{BD}+\mathrm{GP}$ and $\mathrm{BD}+\mathrm{BC}$, using the EIS technique. The EIS tests were performed at room temperature in an electrochemical cell of two identical working electrodes placed $0.5 \mathrm{~mm}$ from each other for 15 days. The electrodes' area was equal to $8.04 \mathrm{~cm}^{2}$. EIS measurements were carried out at OCP in frequency range $100 \mathrm{kHz}$ to $0.5 \mathrm{mHz}$ and $50 \mathrm{mV}$ sinusoidal perturbation amplitude.

\section{Results and Discussion}

\subsection{Immersion test}

The immersion test indicated the highest corrosivity in pure biodiesel. It showed that the three tested products worked as corrosion inhibitors (Figure 2). Propyl gallate presented the greater efficiency, as it is shown in Table 1. 


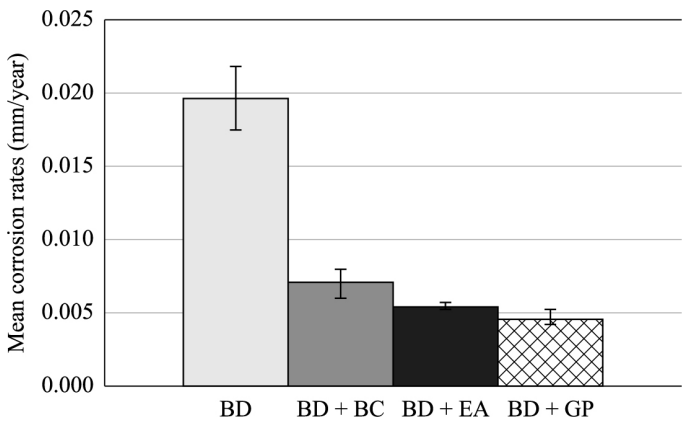

Figure 2. Immersion test result.
Figure 3 presents the images obtained from the surfaces of the coupons after the immersion test using a scanning electron microscope, with 500x amplification. The figure evidences the corrosive attack caused by pure biodiesel, whereas the coupons exposed to biodiesel with additives presented no changes on their surfaces. It indicates less aggressiveness from the medium.

The iron, as well as their oxides, are reactive with organic acids. The following reactions may take place during the corrosion process.

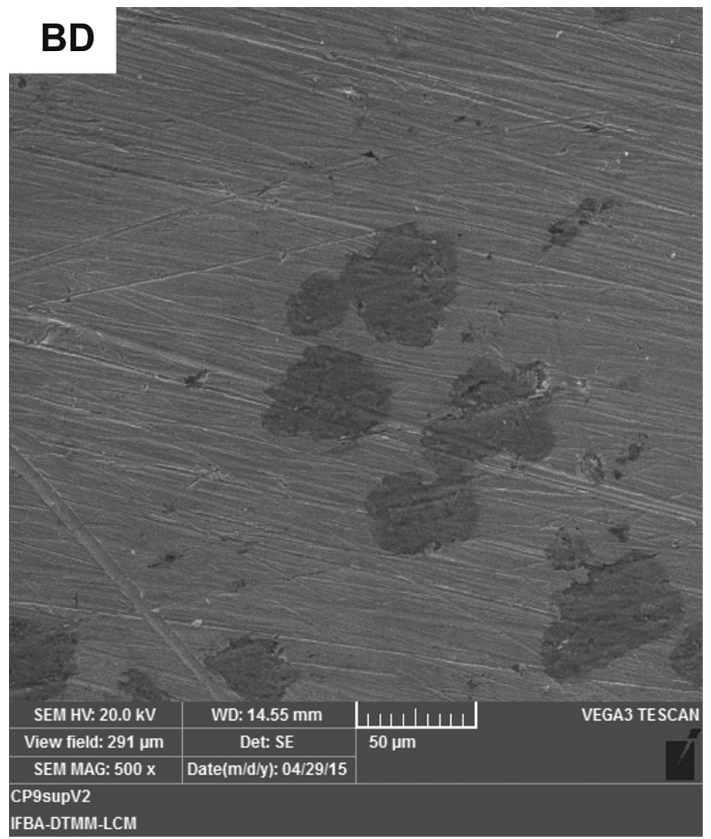

$B D+G P$

\section{$B D+A E$}

\begin{tabular}{|c|c|c|c|}
\hline SEM HV: $20.0 \mathrm{kV}$ & WD: $14.69 \mathrm{~mm}$ & ШШ山ШШ & VEGA3 TESCAN \\
\hline View field: $291 \mu \mathrm{m}$ & Det: SE & $50 \mu \mathrm{m}$ & \\
\hline SEM MAG: $500 \mathrm{x}$ & Date(m/d/y): 04/29/15 & & \\
\hline
\end{tabular}

$B D+B C$

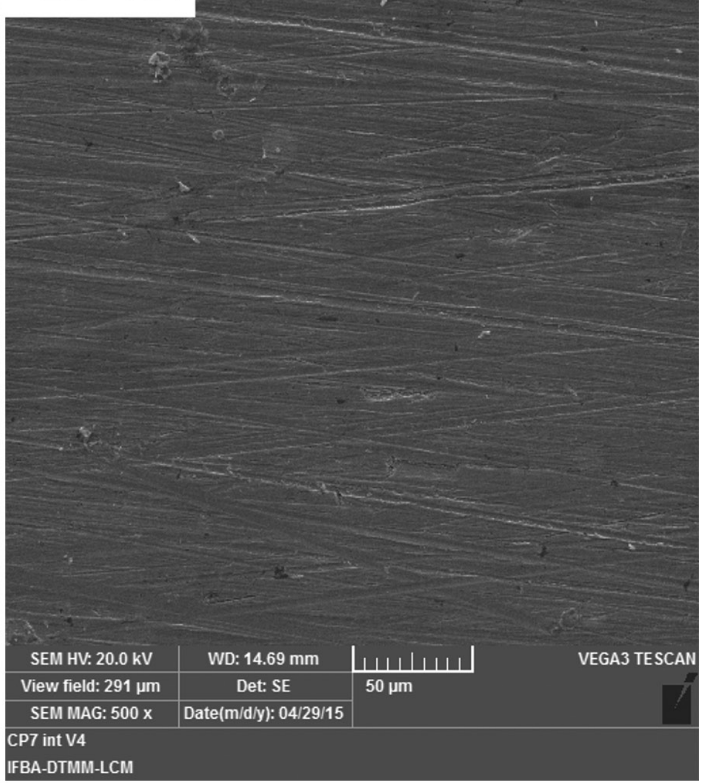

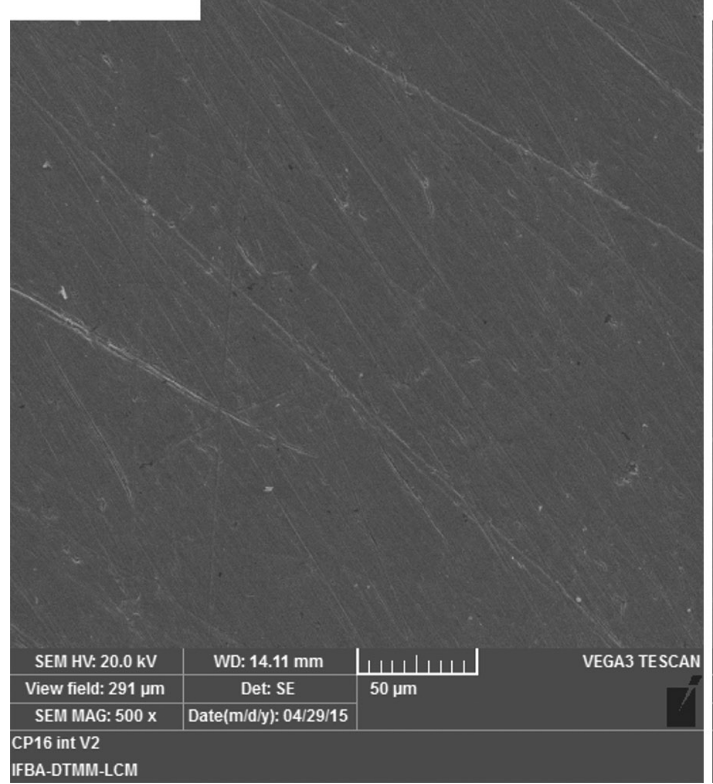

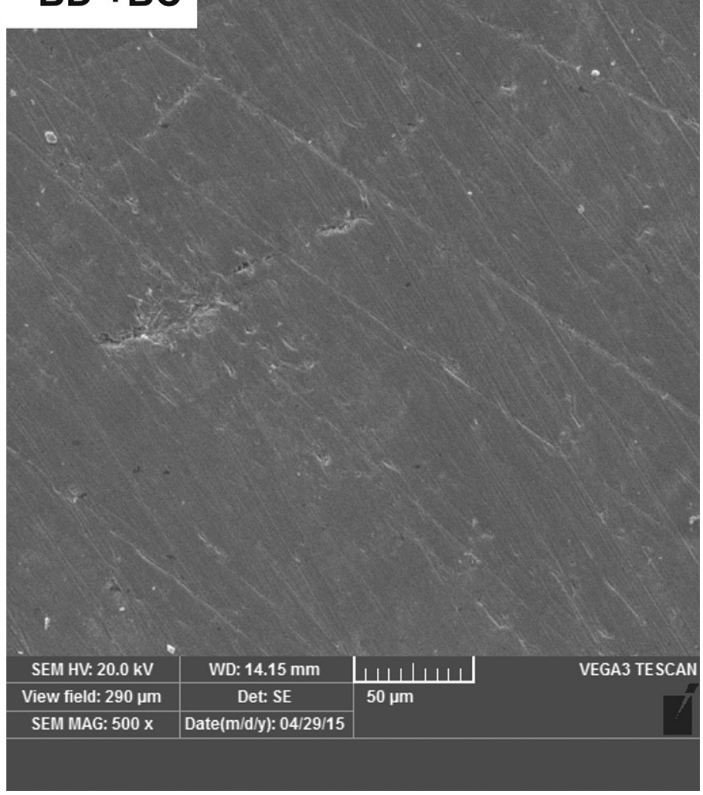

Figure 3. Micrographs (SEM) of surface after exposure to biodiesel in presence (400 ppm) and absence of different corrosion inhibitors. 
Table 1. Immersion test result.

\begin{tabular}{|c|c|c|c|c|c|}
\hline \multirow[t]{2}{*}{ System } & \multirow[t]{2}{*}{ Coupon } & Corrosion Rate & $\begin{array}{c}\text { Mean Corrosion } \\
\text { Rate } \\
\end{array}$ & \multirow{2}{*}{$\begin{array}{l}\text { Standard } \\
\text { Deviation }\end{array}$} & \multirow[t]{2}{*}{ Efficiency } \\
\hline & & mm/year & mm/year & & \\
\hline \multirow{3}{*}{$\begin{array}{l}\text { Pure biodiesel } \\
\text { (BD) }\end{array}$} & 1 & 0.023 & 0.019 & 0.0021 & - \\
\hline & 2 & 0.018 & & & \\
\hline & 3 & 0.018 & & & \\
\hline \multirow{3}{*}{$\begin{array}{l}\text { Biodiesel with } \\
\text { beta-carotene }(\mathrm{BD}+\mathrm{BC})\end{array}$} & 1 & 0.008 & 0.007 & 0.0010 & $62 \%$ \\
\hline & 2 & 0.008 & & & \\
\hline & 3 & 0.006 & & & \\
\hline \multirow{3}{*}{$\begin{array}{l}\text { Biodiesel with propyl } \\
\text { gallate }(\mathrm{BD}+\mathrm{GP})\end{array}$} & 1 & 0.003 & 0.003 & 0.0002 & $83 \%$ \\
\hline & 2 & 0.003 & & & \\
\hline & 3 & 0.003 & & & \\
\hline \multirow{3}{*}{$\begin{array}{l}\text { Biodiesel with stearic } \\
\text { acid (BD+EA) }\end{array}$} & 1 & 0.005 & 0.005 & 0.0005 & $75 \%$ \\
\hline & 2 & 0.004 & & & \\
\hline & 3 & 0.004 & & & \\
\hline
\end{tabular}<smiles>[R]C(=O)OC(=O)O</smiles>

Figure 4. Propyl gallate action as an antioxidant.

$$
\begin{aligned}
& 4 \mathrm{Fe}+3 \mathrm{O} 2 \rightarrow 2 \mathrm{Fe} 2 \mathrm{O} 3 \\
& \mathrm{Fe} 2 \mathrm{O} 3+6 \mathrm{R}^{\prime} \mathrm{COOH} \rightarrow 2 \mathrm{Fe}\left(\mathrm{R}^{\prime} \mathrm{COO}\right) 3+3 \mathrm{H} 2 \mathrm{O} \\
& 2 \mathrm{RCOOH}+\mathrm{Fe} \rightarrow \mathrm{Fe}\left(\mathrm{R}^{\prime} \mathrm{COO}\right)+\mathrm{H} 2
\end{aligned}
$$

Therefore, metal weights were reduced after stearic. Acid tests and beta - carotene acted as an antioxidant in biodiesel retarding the formation of free radicals that cause the reduction of its corrosivity Propyl gallate is a secondary metabolite of the simple phenolic compounds group. It is widely found in several plants and works as primary antioxidant - free radicals receiver. It also delays, inhibits or interrupts the propagation of biodiesel's fatty esters self-oxidation reactions. The phenolic hydrogen is dissociable; therefore, it is capable of forming stable free radicals by inhibiting the start or the spread of biodiesel oxidation; as shown in Figure 4.

\subsection{NACE TM-0172 Test}

As it was shown in Figure 5, only the coupon of the immersed test conducted in pure biodiesel staining presented the corrosive behavior. The biodiesel additive test did not show any stains. Therefore, the three tested products inhibited the corrosive action of biodiesel on carbon steel.

The Degradation of biodiesel increases their corrosivity causing the release of metal ions on the surface of the metal. This liberation works as a catalyst of chemical reactions in the formation of free radicals. Thus, biodiesel degradation speeds up. The water addition in the NACE test simulated the contaminated biodiesel condition, making the system more corrosive. Despite the most severe conditions, the three additives appeared to be effective. This observation confirms the harmful effect of the presence of metallic ions

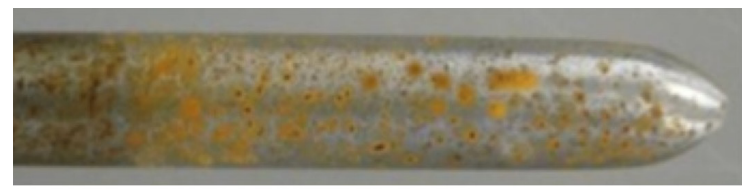

(a)

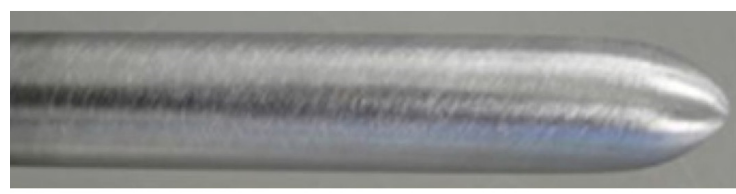

(b)

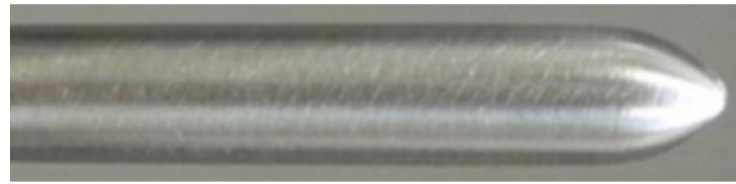

(c)

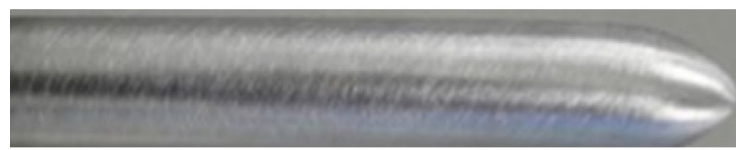

(d)

Figure 5. NACE TM 172 - test result (a) pure biodiesel; (b) biodiesel with stearic acid; (c) biodiesel with propyl gallate; (d) biodiesel with beta-carotene.

\subsection{EIS test}

The demanded assumptions for fluke, linearity and stability in the trials were tested and validated through Kramers-Kronig transformation methodology. The equivalent 


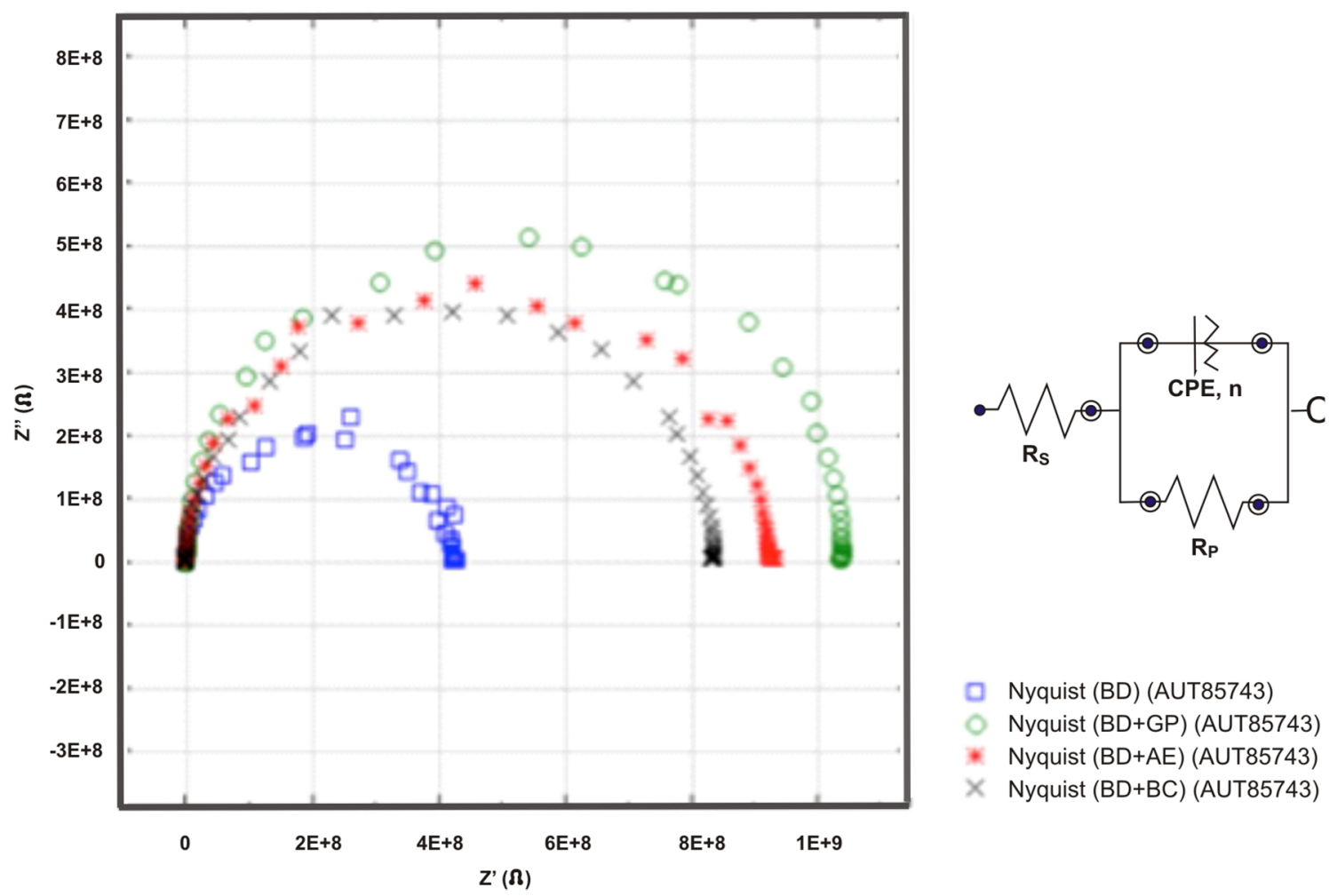

Figure 6. Nyquist impedance plots. (BD) pure biodiesel; (BD+AE) biodiesel with stearic $(\mathrm{BD}+\mathrm{GP})$; biodiesel with propyl gallate; $(\mathrm{BD}+\mathrm{BC})$ biodiesel with beta-carotene.

Table 2. Data of the trials set by the equivalent circuit.

\begin{tabular}{ccccccc}
\hline Cell & OCP $(\mathbf{V})$ & Rp.R $(\boldsymbol{\Omega})$ & Rs.R $(\boldsymbol{\Omega})$ & CPE $($ Y0) & CPE (n) & $\boldsymbol{\chi}^{\mathbf{2}}$ \\
\hline BD & 0.009 & $4.183 \mathrm{E}+8$ & 850.23 & $2.9514 \mathrm{E}-11$ & 0.997 & 0.0547 \\
BD + GP & -0.009 & $1.037 \mathrm{E}+9$ & 837.36 & $4.0246 \mathrm{E}-11$ & 0.998 & 0.0238 \\
BD + AE & 0.004 & $9.118 \mathrm{E}+8$ & 604.90 & $4.234 \mathrm{E}-11$ & 0.994 & 0.0627 \\
BD + BC & 0.002 & $8.304 \mathrm{E}+8$ & 582.74 & $4.725 \mathrm{E}-11$ & 0.990 & 0.0444 \\
\hline
\end{tabular}

circuit presented on Figure 6 was selected according to the complex non-linear least square fitting method

Figure 6 shows the Nyquist impedance plots of carbon steel exposed to four different electrolytes for 15 days. Table 2 presents data of the trials applied to the equivalent circuit.

These results indicate higher corrosivity of pure biodiesel and show that the three tested additives reduced the fuel's corrosivity. Propyl gallate was the most effective additive for corrosion inhibition. These results match those from the immersion and NACE tests.

\section{References}

1. Quintella CM, Teixeira LSG, Korn MGA, Costa-Neto PR, Torres EA, Castro MP, et al. Cadeia do biodiesel da bancada à indústria: uma visão geral com prospecção de tarefas e oportunidades para P\&D\&I. Quimica Nova. 2009; 32(3):793808. http://dx.doi.org/10.1590/S0100-40422009000300022.

2. Singh B, Korstad J and Sharma YC. A critical review on corrosion of compression ignition (CI) engine parts by biodiesel and biodiesel blends and its inhibition. Renewable

\section{Conclusion}

- Pure biodiesel showed higher corrosivity

- The positive inhibitive effects of the natural products tested in biodiesel to control its corrosivity effect on carbon steel have been confirmed.

- Propyl gallate was the most effective product (83\% effectiveness) followed stearic acid $(75 \%)$ and Beta-carotene with $(62 \%)$

\& Sustainable Energy Reviews. 2012; 16(5):3401-3408. http:// dx.doi.org/10.1016/j.rser.2012.02.042.

3. Aquino IP, Hernandez RPB, Chicoma DL, Pinto HPF and Aoki IV. Influence of light, temperature and metallic ions on biodiesel degradation and corrosiveness to copper and brass. Fuel. 2012; 102:795-807. http://dx.doi.org/10.1016/j.fuel.2012.06.011.

4. Fazal MA, Haseeb ASMA and Masjuki HH. Comparative corrosive characteristics of petroleum diesel and palm biodiesel for automotive materials. Fuel Processing Technology. 2010; 91(10):1308-1315. http://dx.doi.org/10.1016/j.fuproc.2010.04.016. 
5. Fernandes DM, Montes R, Almeida ES, Nascimento AN, Oliveira PV, Richter EM, et al. Storage stability and corrosive character of stabilised biodiesel exposed to carbon and galvanized steels. Fuel. 2013; 107:609-614. http://dx.doi.org/10.1016/j. fuel.2012.11.010.

6. Knothe G and Dunn RO. Dependence of oil stability index of fatty compounds on their structure and concentration and presence of metals. Journal of the American Oil Chemists Society. 2003; 80(10):1021-1026. http://dx.doi.org/10.1007/ s11746-003-0814-x.

7. Sarin A, Arora R, Singh NP, Sharma M and Malhotra RK. Influence of metal contaminants on oxidation stability of Jatropha biodiesel. Energy. 2009; 34(9):1271-1275. http:// dx.doi.org/10.1016/j.energy.2009.05.018.

8. Rangel HA. Emprego da técnica de emissão por fluorescência de ultravioleta no monitoramento de inibidores de corrosão em água produzida. [Dissertation]. Rio de Janeiro: Universidade do Estado do Rio de Janeiro; 2009.

9. Bentiss F, Lebrini M, Vezin H and Lagrenée M. Experimental and theoretical study of 3-pyridyl-substituted 1,2,4-thiadiazole and 1,3,4-thiadiazole as corrosion inhibitors of mild steel in acidic media. Materials Chemistry and Physics. 2004; 87(1):18-23. http://dx.doi.org/10.1016/j.matchemphys.2004.05.040.

10. Quraishi MA and Ansari FA. Fatty acid oxadiazoles as corrosion inhibitors for mild steel in formic acid. Journal of
Applied Electrochemistry. 2006; 36(3):309-314. http://dx.doi. org/10.1007/s10800-005-9065-z.

11. Hancsók J, Bubálik M, Beck Á and Baladincz J. Development of multifunctional additives based on vegetable oils for high quality diesel and biodiesel. Chemical Engineering Research \& Design. 2008; 86(7):793-799. http://dx.doi.org/10.1016/j. cherd.2008.03.011.

12. Almeida ES, Portela FM, Sousa RMF, Daniel D, Terrones $\mathrm{MGH}$, Richter EM, et al. Behaviour of the antioxidant tertbutylhydroquinone on the storage stability and corrosive character of biodiesel. Fuel. 2011; 90(11):3480-3484. http:// dx.doi.org/10.1016/j.fuel.2011.06.056.

13. Jakeria MR, Fazal MA and Haseeb ASMA. Effect of corrosion inhibitors on corrosiveness of palm biodiesel. Corrosion Engineering, Science and Technology. 2015; 50(1):56-62. http://dx.doi.org/10.1179/1743278214Y.0000000208.

14. Dingfeng J, Xuehua Z, Panpan W, Li J and Hongliang G. Corrosion behavior of ASTM 1045 mild steel in palm biodiesel. Renewable Energy. 2015; 81:457-463. http://dx.doi.org/10.1016/j. renene.2015.03.022.

15. Yoo S-H, Kim Y-W, Chung K, Baik S-Y and Kim J-S. Synthesis and corrosion inhibition behavior of imidazoline derivatives based on vegetable oil. Corrosion Science. 2012; 59:42-54. http://dx.doi.org/10.1016/j.corsci.2012.02.011. 